\title{
MENGKONSTRUKSI KETERAMPILAN SEBAGAI PEMBAWA ACARA PADA PENGURUS PKK DESA KARANGREJO KABUPATEN KARANGANYAR
}

\author{
Miftakhul Huda', Ayu Rahmawati ${ }^{2)}$, Ermira Nilansari Putri ${ }^{3)}$ \\ Pendidikan Bahasa dan Sastra Indonesia, Universitas Muhammadiyah Surakarta
}

\begin{abstract}
Abstrak
Berbicara tidak sekadar melafalkan bunyi bahasa. Berbicara merupakan kemampuan yang kompleks. Di dalam keterampilan berbicara mengandung kemampuan pemilihan kata, pengendalian emosi, penguasaan audiens, dan wawasan yang luas. Keterampilan berbicara sebagai pembawa acara merupakan keterampilan minimal yang harus dimiliki oleh pengurus PKK. Hal ini penting karena sebagai pengurus, ketika di tingkat RT/ RW atau desa ada kegiatan, idealnya mampu tampil membawakan acara dengan baik. Selain itu, pengurus PKK merupakan orang-orang dipilih dan dipercaya memiliki kemampuan. Pengabdian masyarakat ini termasuk ke dalam jenis pelatihan. Mengontruksi keterampilan berbicara sebagai MC (master of ceremony) atau pembawa acara dilaksanakan di Jl. Onta 1 RT 01 RW 05 Karangrejo, Karanganyar. Peserta pelatihan adalah ketua RT Desa Karangrejo dan pengurus PKK Desa Karangrejo Karanganyar. Indikator keberhasilan kegiatan pengabdian ini adalah peningkatan keterampilan berbicara sebagai pembawa acara. Peningkatan keterampilan dapat dilihat dari sebelum dan sesudah pelatihan. Pretest berbentuk soal tentang keterampilan berbicara dan pembawa acara. Ada peningkatan kemampuan peserta sebesar $69 \%$ setelah dilakukan postest. Meskipun demikian, persentase nilai kenaikan dari masing-masing peserta berbeda. Beberapa peserta memiliki potensi dalam pemilihan diksi, sedangkan peserta lain memiliki potensi dalam kejelasan vokal.
\end{abstract}

Keywords: pembawa acara, berbicara, PKK, pelatihan, konstruksi

\begin{abstract}
Speaking is not just reciting the sound of language. Speaking is a complex ability. In speaking skills contain the ability to choose words, control emotions, control the audience, and broad insight. Speaking skills as a master of ceremonies are the minimum skills that must be possessed by PKK management. This is important because as an administrator, when there is an activity at the $R T / R W$ or village level, it is ideally able to perform well. In addition, PKK administrators are chosen people and are believed to have abilities. Community service is included in the type of training. Construction of speaking skills as an $M C$ (master of ceremonies) or master of ceremonies is held on Jl. Onta 1 RT 01 RW 05 Karangrejo, Karanganyar. The trainees were the head of the Karangrejo Village RT and the management of the Karangrejo Karanganyar Village PKK. An indicator of the success of this community service activity is the improvement of speaking skills as an emcee. Improved skills can be seen from before and after training. Pretests take the form of questions about speaking skills and the host. There was an increase in the ability of participants by $69 \%$ after the posttest. Even so, the percentage increase in the value of each participant is different. Some participants have the potential in choosing diction, while other participants have the potential in vocal clarity.
\end{abstract}

Keywords: master of ceremony, speaking, PKK, training, construction

Correspondence author: Miftakhul Huda,miftakhul.huda@ums.ac.id, Surakarta, Indonesia

This work is licensed under a $C C-B Y-N C$ 


\section{PENDAHULUAN}

Keterampilan berbicara menjadi salah satu indikator kemampuan kognitif seseorang. Keterampilan berbicara yang baik menunjukkan baik pula kemampuan berpikirya. Seseorang yang mempu berbicara dengan baik, yaitu sistematis, pemilihan kata yang tepat, mampu mempengaruhi audiens, dan 'menguasai' emosi audiens, dapat dipastikan seseorang itu pola berpikirnya stabil. Untuk dapat berbicara dengan sistematis dan logis, tentunya membutuhkan argumentasi dan penyusunan proposisi yang baik (Zhdanko, 2019). Kemampuan berargumentasi dan menyusun proposisi dengan tepat dapat dilakukan oleh orang yang memiliki kemampuan berpikir yang mumpuni.

Berbicara tidak sekadar melafalkan bunyi bahasa. Berbicara merupakan kemampuan yang kompleks (Huda, Ghazali, Siswanto, \& Hasanah, 2019). Di dalam keterampilan berbicara mengandung kemampuan pemilihan kata, pengendalian emosi, penguasaan audiens, dan wawasan yang luas (Huda, 2018). Pembicara yang tidak memiliki wawasan yang luas, tidak dapat mengaitkan tema pembicaraan dengan informasi terbaru, sehingga pembicaraan akan monoton dan pendengar akan cenderung bosan. Selain itu, joke atau humor sangat diperlukan. Humor dapat dijadikan daya tarik sehingga pendengar akan antusias mengikuti materi pembicaraan.

Berbicara merupakan sebuah keterampilan. Oleh karena itu, agar seseorang terampil dalam berbicara harus sering latihan (Soyinka, Wai, \& Siu, 2018). Latihan yang terkonsep dan terstruktur akan lebih cepat meningkatkan keterampilan dari pada latihan yang tidak ada arahan dan tahapan yang jelas (List, 2019). Latihan yang terstruktur merupakan latihan yang memiliki tahapan-tahapan dengan pengukuran yang tepat (Yan, Lu, \& Liu, 2019), (Huang, 2017). Melalui pengukuran tersebut, kekurangan dan kelebihan seorang pebelajar dapat dilihat.

Keterampilan berbicara pada hakikatnya diperlukan oleh sebagian besar orang pada masing-masing posisinya di tataran sosial (States, 2018), (Frisson, 2015), (Partington, 2017). Seorang pendakwah sangat memerlukan keterampilan berbicara agar ceramahnya dapat dipahami dan menarik bagi jamaah sehingga seruannya untuk meningkatkan keimanan akan efektif. Demikian halnya bagi pengurus PKK (Pemberdayaan Kesejahteraan Keluarga), keterampilan berbicara yang mumpuni sangat diperlukan. PKK merupakan organisasi sosial yang bersingungan langsung dengan masyarakat. Dengan demikian, pengurus PKK sangat perlu keterampilan berbicara yang memadahi, minimal mampu berbicara sebaga pembawa acara atau master of ceremony (MC).

Di lingkungan RT/ RW atau desa seringkali ada kegiatan dengan cakupan audiens kecil-sedang. Kegiatan tersebut, misalkan peringatan Hari Kemerdekaan, peringatan keagamaan, rapat RT/ RW, dan rapat PKK, membutuhkan pewara atau pembawa acara untuk memimpin dan mengatur agar kegiatan berjalan dengan baik. Oleh karena itu, pengurus organisasi di tingkat itu setidaknya memiliki keterampilan berbicara minimal.

Keterampilan berbicara sebagai pembawa acara merupakan keterampilan minimal yang harus dimiliki oleh pengurus PKK. Hal ini penting karena sebagai pengurus, ketika di tingkat RT/ RW atau desa ada kegiatan, idealnya mampu tampil membawakan acara dengan baik. Selain itu, pengurus PKK merupakan orang-orang dipilih dan dipercaya memiliki kemampuan. Di samping itu, pengurus PKK sebagai salah satu penggerak masyarakat perlu memberikan contoh, dalam hal ini contoh berkomunikasi dengan baik. 
Masyarakat di Desa Karangrejo Kabupaten Karanganyar merupakan salah satu desa dengan organisasi PKK yang aktif. Beberapa kegiatan sering dilaksanakan oleh masyarakat setempat. Selain itu, masyarakat cukup bertumpu pada pengurus PKK ketika kegiatan desa diadakan. Di sisi lain, keterampilan berbicara pengurus PKK dipandang perlu dikonstruksi. Dikonstruksi melalui pelatihan dan pemberian wawasan sehingga secara individu sadar bahwa keterampilan berbicara sangat penting (Huda, Kustanti, \& Rufiah, 2019), (Huda, Syukur, \& Siswanto, 2020). Kesadaran tersebut akan membuat pengurus PKK sadar dan secara aktif mengonstruksi kemampuannya dalam keterampilan berbicara.

Situasi tersebut menjadi pertimbangan bahwa mengonstruksi keterampilan berbicara pengurus PKK Desa Karangrejo Kabupaten Karanganyar sangat diperlukan. Kegiatan konstruksi keterampilan ini bertujuan menumbuhkan kesadaran para pengurus untuk meningkatkan keterampilan berbicara yang dimiliki dan sadar bahwa keterampilan berbicara sangat diperlukan. Dengan proses kontruksi, pengurus PKK diharapkan memiliki kecakapan dalam keterampilan berbicara.

Permasalahan yang dihadapi mitra adalah kurangnya tereksplorasi keterampilan berbicara pengurus PKK Desa Karangrejo Kabupaten Karanganyar. Di sisi lain, sebagai pengurus PKK dituntut untuk dapat berbicara di depan umum dengan baik. Selain itu, di tingkat desa sering kali diadakan kegiatan dengan skala audiens kecil-menengah.

Peningkatan keterampilan berbicara sebagai pembawa acara dilakukan dengan cara mengkonstruksi kemampuan peserta melalui pemberian wawasan dan pelatihan. Wawasan diberikan dalam bentuk manteri tentang apa dan bagaimana menjadi pembawa acara yang baik, pentingnya kemampuan menjadi master of ceremony, dan hal-hal dasar dalam keterampilan berbicara. Pelatihan dilakukan dengan unjuk kerja satu persatu.

\section{METODE PELAKSANAAN}

Pengabdian masyarakat ini termasuk ke dalam jenis pelatihan. Peserta pengabdian masyarakat dilatih keterampilan berbicara sebagai pembawa acara. Pelatihan ini didahului dengan pemberian materi tentang keterampilan berbicara dan pembawa acara, kemudian dilanjutkan dengan praktik satu persatu, dan diakhiri evaluasi. Dengan demikian, peserta memiliki dasar pengetahuan, filosofi, dan keterampilan sehingga mampu mengonstruksi kemampuan berbicara.

Mengontruksi keterampilan berbicara sebagai MC (master of ceremony) atau pembawa acara dilaksanakan Rabu, 11 Desember 2019 di Jl. Onta 1 RT 01 RW 05 Karangrejo, Karanganyar. Peserta pelatihan adalah ketua RT Desa Karangrejo dan pengurus PKK Desa Karangrejo Karanganyar. Indikator keberhasilan kegiatan pengabdian ini adalah peningkatan keterampilan berbicara sebagai pembawa acara. Peningkatan keterampilan dapat dilihat dari sebelum dan sesudah pelatihan. Sebelum pelatihan keterampilan peserta diukur dengan menggunakan pretest dan keterampilan pascapelatihan diukur dengan menggunakan posttest.

Teknik validasi yang digunakan untuk melihat peningkatan keterampilan berbicara menggunakan triangulasi. Triangulasi yang digunakan aadalah triangulasi sumber. Selain berdasarkan penilaian yang dilakukan oleh tim pengabdian, peserta lain juga diberikan kesempatan untuk memberikan masukan dan pandangan terhadap 
kemampuan peserta lain. Masukan dan pendapat dari peserta lain dijadikan sebagai triangulasi dalam pengabdian masyarakat ini.

\section{HASIL DAN PEMBAHASAN}

Mengonstruksi keterampilan berbicara sebagai pembawa acara dipandang penting bagi pengurus RT dan PKK Desa Karangrejo Kabupaten Karanganyar. Sebagai pemimpin pada level akar rumput dan bersinggungan langsung dengan masyarakat tentu dituntut dapat menjadi contoh yang baik dan dianggap mumpuni dalam banyak hal. Selain itu, kegiatan yang melibatkan masyarakat secara langsung dalam jumlah yang tidak sedikit tentu sering dilakukan. Kegiatan tersebut perlu dikelola dengan baik. Dikelola dalam arti dipimpin dengan urutan yang cantik Dengan demikian, posisi pembawa acara di organisasi tingkat akar rumput bersifat fundamental (Clonan-roy, Wortham, \& Nichols, 2016). Untuk mengetahui kemampuan awal peserta, dilakukan pretest. Pretest berbentuk soal tentang keterampilan berbicara dan pembawa acara. Selain itu, kemampuan awal sebagai pembawa acara juga dilihat dengan cara praktik singkat. Nilai pretest tersebut disajikan dalam tabel 1.

Tabel 1. Nilai pretest peserta pelatihan

\begin{tabular}{cc}
\hline No. Peserta & Nilai Pretest \\
\hline 1. & 60 \\
2. & 60 \\
3. & 65 \\
4. & 67 \\
5. & 75 \\
6. & 50 \\
\hline
\end{tabular}

Peserta pengabdian masyarakat yang berjumlah 6 orang memiliki nilai pretest dalam rentangan 50 sampai dengan 75. Aspek yang dinilai adalah kejelasan vokal, intonasi, ekspresi, kevalidan isi, dan penampilan. Berdasarkan aspek tersebut dapat dilihat bahwa perbandingan antara aspek performansi dan kompetensi adalah 4:1. Aspek performansi adalah kejelasan vokal, intonasi, ekspresi, dan penampilan. Aspek kompetensi adalah kevalidan isi. Aspek performansi berkaitan dengan sesuatu yang dapat dilihat, sedangkan kompetensi berkaitan dengan aspek kognitif (Wongsila \& Yuenyong, 2019). Perpaduan unsur performansi yang dominan disebabkan karena berbicara merupakan sebuah keterampilan. Keterampilan dapat diwujudkan dengan latihan (Yan et al., 2019). Oleh karena itu, aspek latihan akan sangat penting dalam mengonstruksi keterampilan berbicara (Anh, James, \& Pittock, 2018). Meskipun aspek kompetensi hanya sebesar $20 \%$, unsur ini tidak dapat diremehkan. Kualitas pembicaraan seseorang juga dilihat dari kevalidan isi pembicaraan. Apabila dirata-rata, capaian nilai pretest adalah 62,8. Nilai tersebut dirasa perlu ditingkatkan. Nilai pretest dapat dilihat dalam grafik 1. 


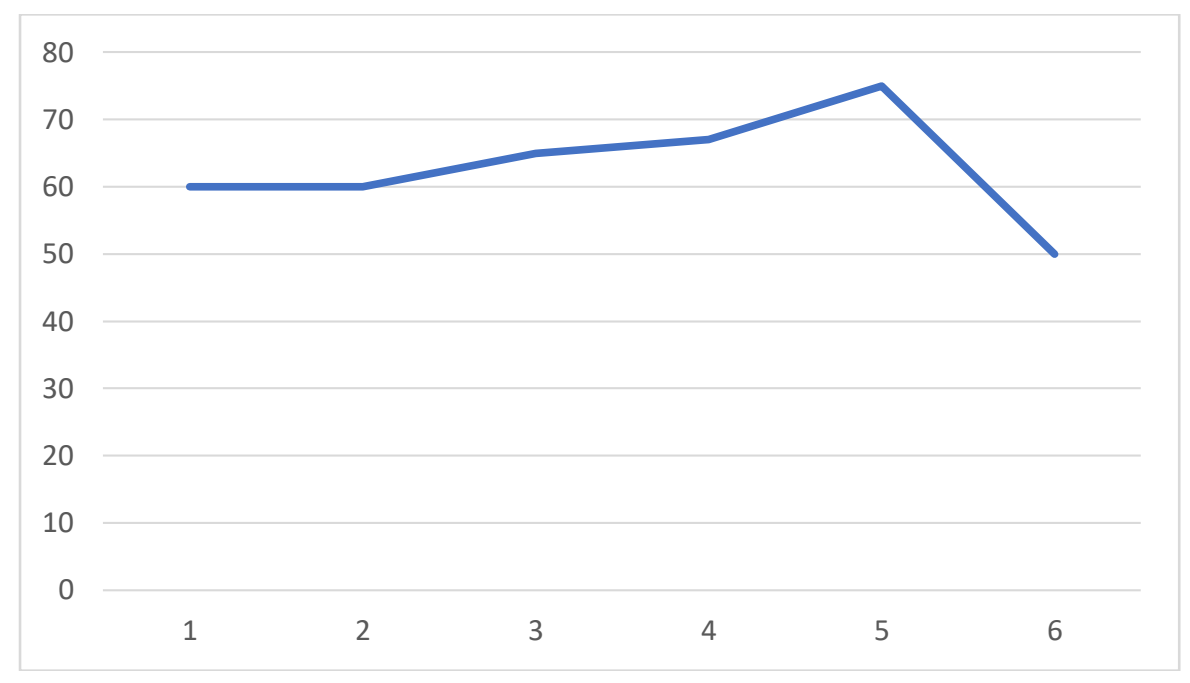

Grafik 1 menunjukan kecakapan awal peserta sebagian besar di bawah standar minimal. Standar minimal kterampilan berbicara dalam pengabdian ini ditetapkan dengan nilai 70. Dengan demikian, hanya ada satu peserta yang memiliki kecakapan awal minimal. Kondisi tersebut menunjukan bahwa pelatihan ketermpilan berbicara sebagai pembawa acara sangat diperlukan mengingat peran sebagai pemimpin organisasi pada level akar rumput sangat penting. Ada beberapa kendala yang dirasakan peserta dalam upaya peningkatan keterampilan berbicara. Beberapa peserta mengungkapkan kendala yang dihadapi. Kendala tersebut di antaranya sebagai berikut.

Rasa cemas

Rasa cemas menjadi salah satu kendala bagi peserta dalam meningkatkan keterampilan berbicara sebagai pembawa acara. Rasa cemas ini muncul karena ada ketakutan dalam diri peserta takut melakukan kesalahan. Selain itu, peserta merasa malu apabila penampilannya tidak menarik. Peserta merasa tidak percaya diri. Hal demikian dapat di atasi dengan cara memperluas wawasan (Stock \& Eik-nes, 2016). Dengan banyak wawasan, peserta memiliki banyak referensi dalam membawakan acara sehingga perlahan akan mengurangi rasa cemas.

Belum berpengalaman

Kendala kedua yang dirasakan oleh peserta adalah kurangnya pengalaman menjadi seorang pembawa acara. Kurangnya ruang yang diberikan kepada peserta menjadikan peserta lebih menjauh dari kata kompeten dalam keterampilan berbicara (Birbili, 2018). Terkadang, peserta justru yang menghindar ketika ada kesempatan menjadi seorang pembawa acara pada kegiatan di desa. Kendala ini dapat di atasi dengan cara memperbanyak latihan.

Kesulitan memilih diksi yang tepat

Kesulitan memilih diksi yang tepat menjadi kendala berikutnya bagi peserta ketika menjadi pembawa acara. Oleh karena itu, seringkali peserta membuat konsep terlebih dahulu. Akan tetapi, hal ini memiliki kelemahan. Peserta kurang bisa memberikan improvisasi atas konsep yang telah dibuat. Dengan demikian, tugas sebagai pembawa acara menjadi terkesan monoton dan tidak berkembang (Silverstein, 2015).

Peserta diberikan materi tentang keterampilan berbicara. Materi tersebut termasuk di dalamnya kaidah ketatabahasaan. Hal ini penting, dengan menguasai ketatabahasaan, peserta akan memahami diksi dan pengucapan yang benar dan salah (Shao \& Purpur, 2016). Penguasaan keterampilan kebahasan akan menempatkan peserta sebagai sosok 
yang mampu berkata dengan baik dan benar. Perkataan yang baik mengacu pada norma kesusilaan. Dengan demikian, perkataan yang baik berkaitan dengan sopan santun. Perkataan yang benar berkaitan dengan gramatikal (Ariel \& Iris, 2019). Perkataan yang baik belum tentu benar secara gramatikal dan pernyataan yang benar secara gramatikal belum tentu baik. Oleh karena itu, penguasaan kebahasaan bagi peserta sangat penting. Selain itu, peserta akan memiliki wawasan tentang keterampilan berbicara sehingga memahami berbagai ekspresi, nada, dan tempo pengucapan.

Dalam pemberian materi, peserta juga diberikan wawasan tentang susunan acara dan cara membuat draf susunan acara. Setelah itu, peserta akan mengembangkan draf masing-masing. Draf yang telah dikembangkan kemudian dipraktikan oleh masingmasing peserta. Pengetahuan tentang susunan acara sangat penting bagi seorang pembawa acara. Pembawa acara harus mampu menempatkan urutan yang tepat sebagai satu rangkaian kegiatan. Selain urutan kegiatan, pembawa acara perlu mengetahui susunan orang-orang yang harus memberikan prakata di awal beserta urutannya. Hal ini penting karena membawa simbol penghormatan. Orang yang paling dihormati dipersilakan berbicara paling awal atau paling akhir perlu dipertimbangkan dengan baik.

Setiap peserta diberikan kesempatan praktik. Setiap peserta memiliki waktu 15 sampai dengan 30 menit. Ketika satu peserta praktik menjadi pembawa acara, peserta yang lain berperan sebagai peserta sekaligus observer. Peserta secara bergantian praktik menjadi pembawa acara, kemudian diberikan komentar dari peserta lain. Setelah semua peserta praktik dan berikan masukan satu persatu, berikutnya adalah posttest.

Tabel 2. Nilai posttest peserta pelatihan

\begin{tabular}{cc}
\hline No. Peserta & Nilai Posttest \\
\hline 1. & 90 \\
2. & 93 \\
3. & 88 \\
4. & 90 \\
5. & 95 \\
6. & 85 \\
\hline
\end{tabular}

Tabel 2 menunjukan nilai posttest. Berdasarkan tabel 2 dapat dilihat adanya peningkatan keterampilan berbicara sebagai pembawa acara. Rata-rata nilai posttest adalah 90,1. Dengan demikian, ada peningkatan kemampuan peserta sebesar $69 \%$. Peningkatan kemampuan terjadi di semua unsur, baik kejelasan vokal, intonasi, ekspresi, kevalidan isi, maupun penampilan. Nilai yang disajikan dalam tabel 2 menunjukan bahwa semua peserta telah mampu melampaui batas nilai minimal keterampilan berbicara. Nilai terendah adalah 85, sedangkan batas nilai minimal keterampilan berbicara adalah 70. Hal itu menunjukan bahwa kemampuan peserta telah jauh melampaui batas nilai minimal. Perbandingan peningkatan kemampuan peserta dapat dilihat pada gambar 2. 


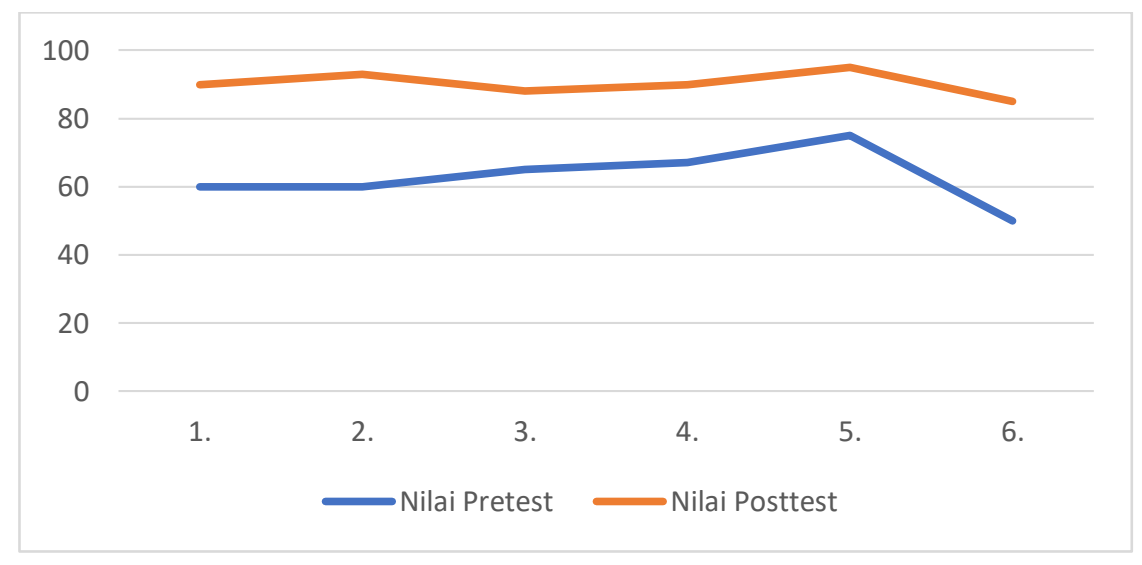

Gambar 2 menunjukan adanya peningkatan kemampuan peserta yang signifikan. Semua peserta mengalami kenaikan kemampuan dalam keterampilan berbicara. Meskipun demikian, persentase nilai kenaikan dari masing-masing peserta berbeda. Nilai masing-masing peserta mengalami variasi peningkatan. Beberapa peserta memiliki potensi dalam pemilihan diksi, sedangkan peserta lain memiliki potensi dalam kejelasan vokal. Peningkatan pada aspek yang berbeda bergantung pada komentar yang disampaikan oleh rekan ketika melakukan pretest. Ketika rekan peserta fokus pada kejelasan vokal, maka akan menyampaikan terkait kejelasan vokal peserta dalam peran menjadi pembawa acara. Dengan demikian, peserta akan mengembangkan diri dalam hal kejelasan vokal. Berdasarkan tersebut menunjukan bahwa semua aspek dapat dikembangkan. Hanya saja, pengembangkan aspek keterampilan tidak dapat dilakukan sekaligus. Pengembangan perlu dilakukan secara bertahap. Hal ini menujukkan bahwa latihan memiliki posisi yang penting dalampengembangan keterampilan berbicara.

\section{SIMPULAN}

Mengontruksi keterampilan berbicara sebagai pembawa acara dilakukan dalam bentuk pelatihan. Aspek kemampuan yang dinilai adalah kejelasan vokal, intonasi, ekspresi, kevalidan isi, dan penampilan. Untuk mengetahui kemampuan awal peserta, dilakukan pretest. Pretest berbentuk soal tentang keterampilan berbicara dan pembawa acara. Ada peningkatan kemampuan peserta sebesar $69 \%$ setelah dilakukan postest. Meskipun demikian, persentase nilai kenaikan dari masing-masing peserta berbeda. Beberapa peserta memiliki potensi dalam pemilihan diksi, sedangkan peserta lain memiliki potensi dalam kejelasan vokal.

\section{DAFTAR PUSTAKA}

Anh, T., James, H., \& Pittock, J. (2018). Interaction Social learning through rural communities of practice: Empirical evidence from farming households in the Vietnamese Mekong Delta. Learning, Culture and Social Interaction, 16(October 2017), 31-44. https://doi.org/10.1016/j.lcsi.2017.11.002 
Ariel, C., \& Iris, O. (2019). No communication without manipulation : A causal-de fl ationary view of information. Studies in History and Philosophy of Science, 73, 34-43. https://doi.org/10.1016/j.shpsa.2018.06.003

Birbili, M. (2018). Learning, Culture and Social Interaction Children's interests in the early years classroom : Views, practices and challenges. Learning, Culture and Social Interaction, (November), 0-1. https://doi.org/10.1016/j.lcsi.2018.11.006

Clonan-roy, K., Wortham, S., \& Nichols, B. (2016). Shifting racial stereotypes in late adolescence: Heterogeneous resources for developmental change in the New Latino Diaspora q. Language \& Communication, 46, 51-61. https://doi.org/10.1016/j.langcom.2015.10.003

Frisson, S. (2015). About Bound and Scary Books: The Processing of Book Polysemies. Lingua, 157, 17-35. https://doi.org/10.1016/j.lingua.2014.07.017

Huang, J. C. (2017). What Do Subject Experts Teach about Writing Research Articles? An Exploratory Study. Journal of English for Academic Purposes, 25, 18-29. https://doi.org/10.1016/j.jeap.2016.10.004

Huda, M. (2018). Strategi Berpikir Integratif dalam Pembelajaran Membaca Lintas Kurikulum di Sekolah Dasar. Jurnal Kredo, 1(2), 26-35. https://doi.org/ttps://doi.org/10.24176/kredo.v1i2.1995

Huda, M., Ghazali, A. S., Siswanto, W., \& Hasanah, M. (2019). Cognitive Level of Characters in the Indonesian Novel As a Source of Learning. Journal for the Education of Gifted Young Scientists, 7(5), 931-952. https://doi.org/https://doi.org/10.17478/jegys.623308

Huda, M., Kustanti, E. W., \& Rufiah, A. (2019). Peningkatan Pemilihan Materi Ajar melalui Telaah Buku Teks bagi Guru Bahasa Indonesia di SMP Muhammadiyah Surakarta. Warta LPM, 22(2), 110-119. https://doi.org/https://doi.org/10.23917/warta.v22i2.8671

Huda, M., Syukur, A., \& Siswanto, W. (2020). Literation of Kebinekaan in Indonesian Text Books for Senior High Schools. International Journal of Innovation, Creativity and Change, 12(2), 278-295.

List, A. (2019). Defining Digital Literacy Development: An Examination of Pre-service Teachers' Beliefs. Computers \& Education, 138, 146-158. https://doi.org/10.1016/j.compedu.2019.03.009

Partington, A. (2017). Evaluative Clash, Evaluative Cohesion and How We Actually Read Evaluation in Texts. Journal of Pragmatics, 117, 190-203. https://doi.org/10.1016/j.pragma.2017.06.008

Shao, X., \& Purpur, G. (2016). Effects of Information Literacy Skills on Student Writing and Course Performance. The Journal of Academic Librarianship. https://doi.org/10.1016/j.acalib.2016.08.006

Silverstein, M. (2015). How language communities intersect: Is "superdiversity" an incremental or transformative condition? Language \& Communication, 1-12. https://doi.org/10.1016/j.langcom.2014.10.015

Soyinka, O., Wai, K., \& Siu, M. (2018). Informality, Housing Insecurity , and Social Exclusion; Concept and Case Study Assessment for Sustainable Urban Development. City, Culture and Society, (April 2017), 1-14. https://doi.org/10.1016/j.ccs.2018.03.005

States, U. (2018). Reframing urban street culture: Towards a dynamic and heuristic process model. City, Culture, and Society, (May), 1-7. https://doi.org/10.1016/j.ccs.2018.05.003 
Stock, I., \& Eik-nes, N. L. (2016). Voice Features in Academic Texts: A review of Empirical Studies. Journal of English for Academic Purposes. https://doi.org/10.1016/j.jeap.2015.12.006

WONGSILA, S., \& YUENYONG, C. (2019). Enhancing Grade 12 Students ' Critical Thinking and Problem-Solving Ability in Learning of the STS Genetics and DNA Technology Unit. Journal for the Education of Gifted Young Scientists, 7(2), 215-235. https://doi.org/http://dx.doi.org/10.17478/jegys.549005

Yan, X., Lu, Y., \& Liu, L. (2019). A General Progressive Secret Image Sharing Construction Method. Signal Processing: Image Communication, 71(February 2018), 66-75. https://doi.org/10.1016/j.image.2018.11.002

Zhdanko, A. (2019). Identification of Cognitive Manipulations that Have The Greatest Impact on Students in The Internet. International Journal of Cognitive Research in Science, Engineering and Education (IJCRSEE), 7(1), 35-42. https://doi.org/10.5937/ijcrsee1901035Z 